\title{
Annex I
}

\section{Country/Organization}

Australia

Austria

Belgium

Canada

Czech Republic

Denmark

European Union

Finland

France

Germany

Greece

Hungary

Iceland

Ireland

Italy

Japan

Korea

Luxembourg

The Netherlands

\section{Aid Agency(s) Included}

Department of Foreign Affairs and Trade (DFAT)

Austria Development Agency (ADA)

Belgian Development Agency (Enabel)

Global Affairs Canada

Ministry of Foreign Affairs of the Czech Republic

Danish Development Corporation

EU International Cooperation and Development

Ministry of Foreign Affairs of Finland

Agency Française de Development (AFD); Fonds Français Pour l'Environnment Mondial (FFEM)

Deutsche Gesellschaft für Internationale Zusammenarbeit (GIZ)

Hellenic Aid, Ministry of Foreign Affairs of Greece

Ministry of Foreign Affairs and Trade

International Development Cooperation (Iceida)

Irish Aid

Italian Agency for Development Cooperation (AICS)

Japan International Cooperation Agency (JICA), Environmental

Restoration and Conservation Agency (ERCA)

Korean International Cooperation Agency (KOICA)

LuxDev

Government of Netherlands Development Cooperation 
Development Spending on Modern Pollution

New Zealand

Norway

Poland

Portugal

Slovak Republic

Slovenia

Spain

Sweden

Switzerland

United Kingdom

United States
New Zealand Foreign Affairs and Trade

The Norwegian Agency for Development Cooperation (NORAD)

Polish Aid

Ministry of Foreign Affairs

Slovak Aid

International Development Cooperation of Slovenia

Spanish Agency for International Development Cooperation (Aecid)

Swedish Aid

Swiss Development Cooperation

Department for International Development (DFID)

United States Agency for International Development (USAID) 